\title{
ARTIKELEN
}

\section{Netwerken van netwerken in transit}

\section{De doorvoer van cocaïne via Nederland}

\author{
Vanessa Dirksen, Wouter van der Leest \& Irma Vermeulen
}

In dit artikel beschrijven wij nieuwe kenmerken van de tot nu toe onderbelichte doorvoerhandel van cocaïne via Nederland. Op basis van een diversiteit aan bronnen hebben wij een kwalitatieve sociale netwerkanalyse gemaakt.

De doorvoerhandel via Nederland wordt gedomineerd door polydrugshandel. Opmerkelijk is dat in Nederland hoofdzakelijk stromen van monodrugs binnenkomen, maar dat vooral stromen van polydrugs het land verlaten. Ook blijkt uit ons onderzoek dat cocaïne bestemd voor de Europese afzetmarkten via Nederland kan worden doorgevoerd naar Europese landen waar de cocaïne in eerste instantie is ingevoerd. Dit wordt door ons gekarakteriseerd als pingponghandel. Een ander kenmerk van de handel is dat actoren die betrokken zijn bij de doorvoer van cocaïne via Nederland naar andere landen hoofdzakelijk delen van de cocaïnehandelsketen beheren. Verschillende groepen binnen de cocaïnedistributieketen werken weliswaar samen, maar zij hoeven elkaar niet noodzakelijkerwijs te kennen. Al met al wordt de organisatie van de drugsdistributie in dit artikel gekenschetst als een interdependent transnationaal netwerk van netwerken (NoN). Vervolgonderzoek naar de doorvoerhandel zou een dergelijk transnationaal NoN-perspectief moeten hanteren om de onderlinge afhankelijkheid van de micro-en mesoniveaus van de handel te kunnen bepalen, om uiteindelijk meer zicht te krijgen op de uitwerking hiervan op macroniveau.

\section{Inleiding}

Veel van de Nederlandse georganiseerde criminaliteit is te typeren als transitcriminaliteit, georganiseerde criminaliteit toegespitst op de grensoverschrijdende smokkel of illegale handel van goederen, personen en geld. Nederland is daarbij productieland, doorvoerland of bestemmingsland (Kleemans e.a., 2002). De handel van cocaïne via Nederland is een vorm van transitcriminaliteit. Onderzoek naar de cocaïnehandel is hoofdzakelijk toegespitst op de invoer van cocaïne en de handel in Nederland (Gruter \& Van de Mheen, 2005; Nieuwenhuis e.a., 2016; Staring e.a., 2019; Zaitch, 2002). Doorvoer van cocaïne wordt weliswaar benoemd en soms (op deelaspecten) toegelicht, maar het fenomeen als zodanig is niet onderzocht (Gruter \& Van de Mheen, 2005; Van der Heijden, 2003; De Middeleer e.a., 2018; Van Wijk \& Bremmers, 2011). En dat is bijzonder, omdat daarmee de essentie van transit - doorvoer - onderbelicht blijkt. Sterker nog, de doorvoer van cocaïne vormt een blinde vlek (Nieuwenhuis e.a., 2016; Staring e.a., 2019; Tops e.a., 2018). 
Enerzijds is dit verklaarbaar, omdat de inspanningen van de Nederlandse overheid er vooral op zijn gericht om zo veel mogelijk te voorkomen dat cocaïne Nederland wordt ingevoerd of in Nederland wordt verhandeld; (wetenschappelijke) kennis op dat vlak is dan ook zeer wenselijk. Anderzijds is het bijzonder, omdat het grensoverschrijdende, transnationale karakter van de cocaïnehandel daarmee eenzijdig wordt belicht en dat terwijl gesteld kan worden dat cocaïne die Nederland wordt ingevoerd hoofdzakelijk bestemd is voor afzetmarkten elders. Ter illustratie: het gebruik van cocaïne in Nederland lag rond de 3.600 kilo op jaarbasis. Er zijn aanwijzingen dat het cocaïnegebruik in Nederland de afgelopen jaren licht is gestegen, vooral onder uitgaanspubliek. Hoewel het gebruik van cocaïne daarmee in Nederland boven het Europese gemiddelde ligt, staat het niet in verhouding tot de hoeveelheden cocaïne die Nederland worden ingevoerd (Boerman e.a., 2017; Van Laar e.a., 2020). In Rotterdam alleen al werd in 201613.312 kilo cocaïne onderschept. In 2020 was dit opgelopen tot 40.641 kilo. ${ }^{1}$ Een en ander hangt samen met de sinds 2013 enorme, zij het enigszins gestabiliseerde, toename in de productie van cocaïne in Zuid-Amerika (vooral in Colombia) evenals de toevoer naar Europa (UNODC, 2020). De som van de inbeslagnames kan als ondergrens worden beschouwd van de daadwerkelijke hoeveelheid cocaïne die Nederland binnenkomt.

Om recht te doen aan en meer zicht te krijgen op het transitkarakter van de cocaïnehandel en het functioneren van Nederland als drugsdistributiehub is door ons een verkennend onderzoek gedaan naar de doorvoer van cocaïne via Nederland (Vermeulen e.a., 2018).

Doorvoer hebben wij gedefinieerd als een vorm van tussenhandel waarbij een landsgrens wordt gepasseerd, specifiek van Nederland naar andere landen. De doorvoer van cocaïne is daarmee te typeren als een vorm van transnationale georganiseerde criminaliteit, waarbij criminaliteit over grenzen heen wordt gecoördineerd en de betrokkenheid behelst van subjecten die in meerdere landen actief zijn. De centrale vraagstelling luidt: 'Wat zijn de heersende organisatieprincipes van de doorvoer van cocaïne via Nederland?'

In dit artikel wordt een aantal van onze meest belangwekkende bevindingen nader uitgewerkt in de context van de (criminologische) kennis over organisatieprincipes en netwerken.

\section{Datacollectie en -analyse}

Als aangegeven is het doel van dit onderzoek de organisatieprincipes van de doorvoer van cocaïne via Nederland en de betrokken cocaïnedoorvoernetwerken (later in het artikel getypeerd in termen van netwerken van netwerken) inzichtelijk te maken, en zo een stap verder te gaan dan alleen naar 'kerels en kilo's' te kijken. De term organisatieprincipe omvat zowel de structuren als de coördinatiemechanismen van de sociale organisatie van in dit geval cocaïnedoorvoernetwerken. Waar (sociale) structuur de vorm van handels-/uitwisselingsrelaties (ties) behelst, vormen de coördinatiemechanismen de basis waarop dergelijke relaties tot stand ko-

1 Zie om.nl/onderwerpen/harc-team/jaaroverzichten en om.nl/actueel/nieuws/2021/01/13/harcteam-onderschept-ruim-40.000-kilo-cocaine-in-2020. 
men en in stand worden gehouden. Alleen zicht op de structuur van onderlinge banden is niet voldoende om de complexiteit van de doorvoer te doorgronden. Dat twee mensen zijn verbonden, zegt immers niets over de aard en bestendigheid van die verbinding (vgl. Ianni \& Ianni, 1990, geciteerd in: Innes e.a., 2005). We vertrekken hier vanuit de organisatieliteratuur met betrekking tot ideaaltypen van organiseren (Powell, 1990): hiërarchie, markt en netwerk. Het eerste ideaaltype, de formele organisatie of de hiërarchie, is gebaseerd op autoriteit. Het tweede ideaaltype, markt, is gebaseerd op prijs of, meer algemeen gedefinieerd, de transactie van iets in ruil voor iets anders. Het derde ideaaltype, de netwerkvorm van organiseren, vaart wel bij wederzijds vertrouwen. Oftewel, in de netwerkvorm van organisatie functioneert vertrouwen als een vorm van coördinatie in plaats van - zoals in de hiërarchische organisatie - gehoorzaamheid aan legitiem gezag.

Het verkennende onderzoek naar de organisatieprincipes van de doorvoer van cocaïne is te karakteriseren als een kwalitatieve sociale netwerkanalyse (QSNA), waarbij aandacht is geschonken aan zowel de structuur van de netwerken, in termen van betrokken subjecten, bestemmingslanden en transportmiddelen, als de inhoud van de netwerkrelaties, in termen van onderhandelings- en reputatiemechanismen. Er is in deze verkennende studie gekozen voor de kwalitatieve bestudering van sociale netwerken omdat allereerst begrip vereist is van de eigenheid van de doorvoerhandel, om vervolgens te kunnen begrijpen welke SNA-constructen van betekenis zijn voor de meer wiskundige toepassing van SNA in het onderzoek naar de doorvoer (vgl. Yousefi Nooraie e.a., 2018). Kwalitatieve SNA is van waarde om de contextuele aspecten van netwerkmechanismen (Luxton \& Sbicca, 2020) te belichten en met behulp van de interpretatie van domeinexperts bijvoorbeeld de posities van bepaalde actoren of groepen actoren in een netwerk te duiden.

Van mei 2017 tot juli 2018 is een verscheidenheid aan gegevens verzameld en geanalyseerd. Over de doorvoer van cocaïne was vooralsnog weinig bekend, maar door verschillende bronnen te combineren kon een valide beeld worden opgesteld. Zo is er gebruikgemaakt van open bronnen en politiebronnen.

Open bronnen die we hebben gebruikt, omvatten wetenschappelijke literatuur, mediaberichten en rapporten van onder meer Europol, het UNODC (United Nations Office on Drugs and Crime) en de EMCDDA (European Monitoring Centre for Drugs and Drug Addiction). Op rechtspraak.nl zijn negentien gerechtelijke uitspraken uit de jaren 2016 en 2017 in relatie tot doorvoer van cocaïne bestudeerd om inzicht te krijgen in typen netwerken, werkwijzen en bestemmingen. Voordeel van rechtspraak.nl is dat het gaat om vastgestelde, 'harde' feiten. Een nadeel is dat een procesdossier vaak minder informatie omvat dan alle tijdens een opsporingsonderzoek verzamelde informatie, zoals te vinden in het onderzoeksdossier. Bovendien worden niet alle vonnissen op rechtspraak.nl geplaatst.

Voor wat betreft de politiebronnen hebben we een zoekslag gedaan in het opsporingsregistratiesysteem Summ-IT om - vergelijkbaar met rechtspraak.nl - inzicht te genereren in typen netwerken, werkwijzen en bestemmingen. Aansluitend had het bestuderen van de opsporingsonderzoeken tot doel meer zicht te krijgen in de omvang van de handel. Er is gekeken naar mutaties en processen-verbaal uit de periode januari 2014 tot juli 2018. Hoewel ook intelligencerapporten, preweegvoorstellen en informatieonderzoeken zijn bestudeerd, is voor dit onderzoek al- 
leen die informatie gebruikt die betrekking had op concrete, geconstateerde strafbare feiten. Dit leverde in Summ-IT negen opsporingsonderzoeken op met betrekking tot de doorvoer van cocaïne via Nederland. Dit zijn relatief weinig onderzoeken. Mogelijke oorzaak hiervan kan zijn dat doorvoer van cocaïne in Nederland minder prioriteit heeft dan de import ervan, met als neveneffect dat er minder opsporingsonderzoeken naar plaatsvinden.

Daarnaast is een vragenlijst uitgezet onder de 24 deelnemende landen van het EMPACT Cocaïne \& Heroïne. Dit betreft een samenwerkingsverband dat opereert onder de vlag van Europol en is gericht op de aanpak van de cocaïne- en heroïnehandel naar de Europese Unie en het verstoren van de criminele samenwerkingsverbanden die zich daarmee bezighouden. De vragenlijst was inventariserend van aard en bevatte een combinatie van open en gesloten vragen. Onder meer zijn vragen gesteld over inbeslagnames, de herkomst van de inbeslaggenomen partijen - meer specifiek of cocaïne via Nederland is ingevoerd - en of het betreffende land transit- en/of bestemmingsland voor cocaïne is. Ook is gevraagd naar de mogelijke betrokkenheid van criminele netwerken die in Nederland opereren, naar werkwijzen en of er eventueel sprake is van polydrugshandel. Twintig landen hebben de vragenlijst beantwoord.

$\mathrm{Na}$ het verzamelen en analyseren van de gerechtelijke uitspraken, opsporingsonderzoeken en ingevulde vragenlijsten, hebben we deze onderzoeksbevindingen nader geduid en aangevuld door het afnemen van interviews met opsporingsambtenaren uit binnen- en buitenland. Kennis zit immers vaak in de hoofden van opsporingsambtenaren, maar is niet altijd vastgelegd in de daarvoor geëigende systemen. Tijdens de interviews zijn onder meer vragen gesteld over de mate van persistentie, hoe vraag en aanbod bij elkaar komen, taakverdeling en rollen, typen netwerken en polydrugshandel. Er zijn in totaal 22 semigestructureerde interviews gehouden. Voor wat betreft de informatie uit het buitenland zijn gesprekken gevoerd met medewerkers bij overkoepelende instanties als Europol en MAOC (N) (Maritime Analysis and Operation Centre - Narcotics). Eveneens zijn interviews gehouden met opsporingsambtenaren die werkzaam zijn voor en/of in de ons omringende landen, respectievelijk België, Frankrijk, Duitsland, het Verenigd Koninkrijk en Denemarken. Denemarken omdat volgens Europol dit land als doorvoerland naar Scandinavië fungeert voor cocaïne afkomstig uit Nederland. Vanwege de goede informatiepositie van de Amerikaanse DEA (Drug Enforcement Administration) is tevens gesproken met een van hun foreign liaison officers in Nederland. Al met al zijn negen buitenlandse interviews met in totaal achttien personen afgenomen.

Voor wat betreft de interviews in Nederland is getracht een zo breed mogelijk beeld te genereren door met medewerkers van verschillende organisaties, diensten en disciplines te spreken. Er zijn gesprekken gevoerd met recherche- en informatiemedewerkers uit een aantal regionale politie-eenheden en de Landelijke Eenheid. Ook is een interview gehouden bij de Koninklijke Marechaussee Schiphol. In totaal zijn dertien interviews gehouden met negentien Nederlandse domeinexperts.

Tot slot is politie-informatie (periode 2013-2016) geanalyseerd, waarmee meer zicht is verkregen in de wijze van samenwerken en de onderlinge relaties en ver- 
houdingen tussen subjecten betrokken bij de doorvoer. Vanwege juridische redenen kan de aard van de gebruikte politie-informatie niet nader worden toegelicht. In de data-analyse van het onderzoeksmateriaal zijn allereerst de deelvragen van ons empirisch werk gevolgd, gericht op de algemeen beschrijvende kenmerken van de handel, zoals betrokken subjecten, transportmiddelen, bestemmingen, afscherming en financiën. Vervolgens is een door ons vooraf gedefinieerd codeerschema gehanteerd, afgeleid van het probleemgebied en relevant voor de beschrijving van sociale organisaties. Hieronder vielen de eerdergenoemde drie ideaaltypen van organisatie (formele organisatie, markt en netwerk) en bijbehorende coördinatiemechanismen. Ten slotte zijn codes afgeleid van de verhandelingen over de veranderende aard van hedendaagse georganiseerde criminaliteit, zoals beschreven in Exploring Tomorrow's Organised Crime (Europol, 2015) en in de Serious and Organised Crime Threat Assessment. Crime in the Age of Technology (Europol, 2017). Dit betreft onder andere de codes criminele uitbesteding (crime-as-a-service business model), multiondernemerschap (waaronder polydrugshandel) en cospecialisatie (co-opetition). Hoewel we de datacollectie aanvankelijk hebben benaderd met een op voorhand gedefinieerd codeerschema (top-down coding), zijn tijdens de data-analyseprocedure ook nieuwe codes ontwikkeld op basis van het empirisch materiaal (bottom-up/open coding). Codes die in deze fase van de data-analyse zijn ontwikkeld, zijn onder meer import en doorvoer/alleen doorvoer en aanbod-/ vraaggedreven. Dit artikel behandelt met name de bevindingen uit deze fase van observatiegedreven data-analyse.

\section{Bevindingen}

Nederland vormt in de transnationale cocaïnehandel een belangrijke transit- of distributiehub binnen Europa. Ten aanzien van de positie van Nederland als transithub voor zowel de legale als de illegale handel wordt vaak gesteld dat dit te danken is aan de strategische infrastructurele positie in Europa en de belangrijke havens van Nederland en België. Bij de drugshandel wordt meegelift op bestaande goederen-, geld- en passagiersstromen (Boivin, 2014; Kruisbergen e.a., 2012; Meloen, 2016; Zaitch, 2002).

Uit alle door ons bestudeerde data kan worden opgemaakt dat cocaïne die via $\mathrm{Ne}$ derland wordt verhandeld, hoofdzakelijk is bestemd voor Europese afzetmarkten, specifiek het Verenigd Koninkrijk, Duitsland en Scandinavië. Uit zowel de buitenlandse als de Nederlandse interviews en de bestudering van de politie-informatie is ook naar voren gekomen dat onder meer in de Russische Federatie, Turkije, het Midden-Oosten en in Australië via Nederland verhandelde cocaine wordt afgenomen. Cocaïne wordt hoofdzakelijk ingevoerd via de delta België-Nederland (met name via Antwerpen en Rotterdam), maar ook via andere Europese landen. Uit de interviews, de opsporingsonderzoeken en de politie-informatie blijkt dat Nederlandse groepen toegang hebben tot havens als Hamburg, Bremerhaven, Le Havre en Constanta om cocaïne Nederland binnen te kunnen halen. Daarnaast kan cocaine die via Nederland wordt verhandeld in eerste instantie in Spanje of Italië zijn ingevoerd. 


\section{Pingponghandel}

Een opvallende observatie in ons onderzoek is dat cocaïne bestemd voor de Europese afzetmarkten via Nederland kan worden doorgevoerd naar Europese landen waar de cocaïne in eerste instantie is binnengekomen. Door verschillende geïnterviewden zijn casussen beschreven waarbij bijvoorbeeld een groepering cocaïne vanuit Italië naar Nederland vervoert en een andere groepering cocaïne van Nederland naar Italië doorvoert, of dat cocaïne in Spanje wordt ingevoerd, naar Nederland wordt vervoerd en weer teruggaat richting Spanje. Ook uit de door ons bestudeerde politie-informatie blijkt dat cocaïne vanuit Nederland tevens naar Italië wordt geëxporteerd, terwijl in Italië ook cocaïne bestemd voor Nederland in beslag is genomen (Ministerie van Veiligheid en Justitie, 2017).

Partijen worden dan als het ware via Nederland heen en weer 'gepingpongd' teneinde bij de consumentenmarkten terecht te komen. Het in- en uitvoeren van ladingen cocaïne via Nederland kent daarmee soms verschillende, tegengestelde richtingen (vgl. De Middeleer e.a., 2018; Ministerie van Veiligheid en Justitie, 2017).

Hoewel het kunnen meeliften op de Nederlandse, legale infrastructuur een belangrijke reden kan zijn voor de positie van Nederland als distributiehub in de transnationale drugshandel, verklaart het niet het heen en weer verhandelen van (verschillende ladingen) cocaïne. Dit oogt weinig efficiënt. Daarnaast brengen het afleggen van lange afstanden om drugs te verplaatsen en het passeren van grenzen - zelfs in het Europa met zijn open grenzen - een groter risico om ontdekt te worden met zich mee (De Middeleer e.a., 2018).

Het heen en weer pingpongen van cocaïne doet denken aan herinvoer/heruitvoer als in offshoring, waarbij vanuit land A producten of onderdelen van producten worden verstuurd naar land B voor verwerking ervan, die vervolgens naar land A terug kunnen keren voor verdere verwerking of consumptie (Baldwin, 2017). In het geval van cocaïne zou dit betekenen dat cocaïne bijvoorbeeld in Nederland wordt versneden en dan wordt heringevoerd voor de consumentenmarkt van het Europese land waar de cocaïne in eerste instantie was ingevoerd. Hoewel er in $\mathrm{Ne}$ derland inderdaad sprake is van versnijden en ook versneden partijen naar het buitenland worden doorgevoerd, vindt versnijding voornamelijk plaats in het consumptieland (Van der Heijden, 2003). Het opmerkelijke is dus dat bij de herinvoer/ heruitvoer van cocaïne de handelswaar in ogenschijnlijk onveranderde vorm $\mathrm{Ne}$ derland in- en uitgaat. Daarbij worden partijen in Nederland wel opgedeeld in kleinere partijen, alvorens te worden doorgevoerd.

Een mogelijke verklaring voor pingponghandel zou gelegen kunnen zijn in het feit dat toegang tot de top van de netwerken in Nederland de mogelijkheid biedt om zo zuiver mogelijke cocaïne tegen een relatief lage prijs te verkrijgen. De kwaliteit van drugs die via Nederland wordt verhandeld, is beter, waardoor het aantrekkelijker wordt om drugs in Nederland aan te kopen (Blickman e.a., 2003; De Middeleer e.a., 2018; Tops e.a., 2018). Deze kwaliteitsperceptie leidt ertoe dat cocaïne die in Antwerpen is ingevoerd, naar Nederland wordt doorgevoerd en vervolgens weer kan worden afgezet in België (De Middeleer e.a., 2018).

Wij veronderstellen dat pingponghandel vooral wordt ingegeven door het feit dat de cocaïnehandel hoofdzakelijk wordt gerealiseerd door afzonderlijke netwerken 
van importeurs, leveranciers, logistiek dienstverleners en afnemers, die elkaar niet hoeven te kennen en waarbij Nederland een belangrijk verbindingspunt tussen de verschillende netwerken lijkt te zijn. In de subparagraaf 'Netwerken van netwerken in transit' gaan wij hier dieper op in.

\section{Van mono naar poly}

Uit de interviews, de vragenlijst en de bestudering van opsporingsonderzoeken en gerechtelijke uitspraken blijkt dat de doorvoer van cocaïne via Nederland naar andere landen meestal onderdeel is van polydrugshandel. Er kan sprake zijn van multiondernemerschap waarbij criminelen actief zijn in diverse drugsmarkten (Boerman e.a., 2017; De Middeleer e.a., 2018). Netwerken in de doorvoer van polydrugs hoeven zich daarbij niet altijd op één bestemmingsmarkt te richten: klanten kunnen zich in verschillende landen bevinden. Uit de opsporingsonderzoeken en gerechtelijke uitspraken komt naar voren dat leveranciers ladingen naar diverse bestemmingslanden laten vervoeren, bijvoorbeeld richting Scandinavië en het Verenigd Koninkrijk.

Polydrugshandel kan ook inhouden dat er tussen drugsbranches wordt geswitcht. De politie-informatie en de Nederlandse interviews laten zien dat men bijvoorbeeld 'klein' begint met de uitvoer van hennep en vervolgens de overstap naar harddrugs maakt (vgl. Tops e.a., 2018). Of men begint een heroïnebusiness in het buitenland, na actief te zijn geweest in de cocaïnehandel.

Op basis van de door ons bestudeerde data lijkt polydrugshandel vaak het gevolg van het logistieke proces. Meerdere typen drugs gaan mee op transport afkomstig van een of meerdere leveranciers (cocktailzendingen), of een transportlijn wordt gebruikt voor het vervoer van telkens andere drugs.

Polydrugshandel als zodanig is niet uniek voor Nederland. Volgens Europol handelt een groot deel van de criminele groepen die in Europa betrokken zijn bij de drugshandel, in verschillende soorten drugs (Europol, 2017). Ook in onder meer Noord- en Zuid-Amerika en Australië komt polydrugshandel voor (DEA, 2019; Hughes e.a., 2017). Uniek in de context van polydrugshandel is de positie van $\mathrm{Ne}$ derland als transithub binnen Europa. Naast distributiecentrum voor cocaïne, vinden ook andere geïmporteerde drugs, zoals heroïne, maar ook lokaal geproduceerde drugs, zoals cannabis en synthetische drugs, via Nederland hun weg naar de verschillende bestemmingslanden. Gesteld kan worden dat hoofdzakelijk stromen van monodrugs ons land binnenkomen, dat daarnaast in Nederland drugs geproduceerd worden, en dat vervolgens stromen van polydrugs ons land verlaten: in Nederland worden monodrugshandel en -productie omgezet naar polydrugshandel.

\section{Transitnetwerken}

Uit de Nederlandse en buitenlandse interviews, de bestudeerde opsporingsonderzoeken en gerechtelijke uitspraken is gebleken dat de doorvoer van cocaïne naar het buitenland structureel van aard is en kan plaatsvinden op groothandelsniveau, waarbij partijen van tientallen tot honderden kilo's per keer worden doorgevoerd, en op detailhandelsniveau, waarbij het telkens om gramhoeveelheden gaat. De $\mathrm{Ne}$ derlandse groothandel levert aan groothandel en detailhandel in het buitenland. 
De Nederlandse detailhandel levert hoofdzakelijk aan consumenten in het buitenland. Alle vormen van doorvoer zijn transnationaal van aard. Achttien van de negentien Europese landen die de EMPACT Cocaïne \& Heroïne-vragenlijst hebben ingevuld, hebben aangegeven dat cocaïne onder meer via Nederland naar hun land wordt doorgevoerd.

Uit ons onderzoek blijkt dat de doorvoernetwerken in de mate van organisatie en typen netwerken zeer divers zijn. In de hogere echelons van de markt lijkt een hoge organisatiegraad te zijn: hier zien we stabiele samenwerkingsverbanden met een hoge dichtheid (hoeveelheid relaties) en duidelijke aansturing. Aan de onderkant van de markt is geen sprake van duidelijke aansturing. Samenwerking is meer ad hoc en sterk gedreven door kansen in de markt. Het doorvoernetwerk is hier meer gefragmenteerd en fluïde van karakter en verondersteld kan worden dat groepen die op dit niveau actief zijn, zich snel kunnen aanpassen. Als iemand uitvalt, bijvoorbeeld doordat hij vastzit, wordt zijn werk overgenomen door iemand anders. Hoewel deze doorvoernetwerken als zodanig fluïde en gefragmenteerd zijn, zijn de distributielijnen die doorvoernetwerken exploiteren wel structureel van aard, in de zin dat deze jaren kunnen voortbestaan. Binnen de doorvoer is dus sprake van persisterende structuren, waarbij zeker op het niveau van de groothandel ook sprake is van persisterende daders (vgl. Kruisbergen e.a., 2019).

Ook kan een onderscheid worden gemaakt op basis van het niveau waarop netwerken acteren. Spapens (2012) onderscheidt drie niveaus. Het microniveau omvat de activiteiten en inrichting van criminele samenwerkingsverbanden, oftewel persoonlijke netwerken. Het mesoniveau bestaat uit criminele netwerken die rondom verschillende soorten illegale activiteiten, criminele markten of op geografische wijze zijn geclusterd. Het macroniveau behelst een wereldwijd netwerk van criminele relaties (Spapens, 2012). Gesteld kan worden dat de doorvoernetwerken die in ons onderzoek naar voren zijn gekomen, acteren op het micro- en op het mesoniveau. Het microniveau bestaat uit persoonlijke netwerken van actoren, zoals leveranciers in Nederland, eventuele malafide logistiek dienstverleners en afnemers in het buitenland. Het mesoniveau betreft de transnationale netwerken die zich richten op de doorvoer van cocaïne en andere drugs van Nederland naar het buitenland. Deze netwerken kunnen elk uit meerdere criminele samenwerkingsverbanden bestaan die verder geen rechtstreeks contact met elkaar hoeven te hebben. Er is hier sprake van een netwerk van netwerken (Gao e.a., 2014).

\section{Netwerken van netwerken in transit}

Onze onderzoeksbevindingen wijzen uit dat verschillende transnationale criminele groeperingen beschikken over cocaïnedistributielijnen via Nederland. Uit de interviews is naar voren gekomen dat onder meer Italiaanse maffiagroeperingen, Britse, (etnisch) Albanese en ook Nederlandse groeperingen via Nederland cocaïne distribueren naar verschillende landen (vgl. Ministerie van Veiligheid en Justitie, 2017).

Soms lijkt de doorvoer van cocaïne via Nederland onderdeel te zijn van end-to-endhandel, waarbij de hele cocaïnedistributielijn - van aankoop in Zuid-Amerika tot verkoop aan consumenten - wordt georganiseerd en aangestuurd door één crimineel netwerk. Bij kleinschalige cocaïnehandel kan de distributieketen inderdaad 
bijzonder kort zijn en worden gerealiseerd door één crimineel samenwerkingsverband (het microniveau). Familiebanden spelen dan vaak een belangrijke rol (Gruter $\&$ Van de Mheen, 2005). Voor wat betreft de grootschalige handel achten wij endto-end-handel onwaarschijnlijk, ook al lijkt dat op basis van etniciteit misschien het geval. Zo blijkt dat (etnisch) Albanese criminelen in de regel niet zozeer een groot netwerk vormen, maar dat er eerder sprake is van verschillende, met elkaar samenwerkende netwerken. Zowel in de Nederlandse als in de buitenlandse interviews is daarbij aangegeven dat zij op basis van hun etniciteit toegang kunnen krijgen tot landgenoten die op schakels in de distributieketen over een netwerk beschikken.

Ook informatie uit een van de opsporingsonderzoeken laat zien dat het verschillende, samenwerkende netwerken betreft. Het blijkt dat (etnisch) Albanese criminelen uit de verschillende schakels relatief hoge prijzen moeten betalen voor de cocaïne aan andere (etnisch) Albanese subjecten in de volgende schakel. Dit lijkt te wijzen op een slechte lokale verankering (vgl. Van de Bunt \& Kleemans, 2007).

Italiaanse maffiagroepen beschikken over vergelijkbare afzonderlijke, met elkaar samenwerkende netwerken en ook zij houden zich bezig met de handel in cocaïne via Nederland. De bloemenveiling van Aalsmeer is hiervoor onder meer misbruikt. Bij de handel werken verschillende maffiagroepen samen, bijvoorbeeld clans van de Camorra met clans van de Cosa Nostra (Ministerie van Veiligheid en Justitie, 2017). Voor het risicovolle handwerk stelt een van de buitenlandse geïnterviewden dat Italiaanse subjecten gebruikmaken van (etnisch) Albanese criminelen (vgl. Ministerie van Veiligheid en Justitie, 2017). Voor de import en doorvoer nemen ze regelmatig Nederlandse criminelen in de arm die over de benodigde bedrijven, hulpmiddelen en mensen beschikken.

Op basis van de geraadpleegde bronnen concluderen wij dat de actoren die betrokken zijn bij de doorvoer van cocaïne via Nederland naar andere landen, hoofdzakelijk delen van de cocaïnehandelsketen beheren. Grosso modo is sprake van afzonderlijke netwerken van leveranciers, transporteurs en afnemers die met elkaar samenwerken om de cocaïne van A naar B te krijgen - ook al lijkt het door bijvoorbeeld dezelfde etnische achtergrond van actoren om één groot samenwerkingsverband te gaan.

De leveranciers nemen de cocaïne rechtstreeks van de importeurs of van vervolgschakels in de handelsketen af, bijvoorbeeld de brokers of de tussenhandel. Uit de Nederlandse interviews is naar voren gekomen dat degenen die zich met delen van de keten bezighouden, werkzaam kunnen zijn voor meerdere personen of groepen, bijvoorbeeld voor verschillende afnemers. Op deze wijze kan de handel ook het eenvoudigst georganiseerd worden. Het is niet waarschijnlijk dat er centraal aangestuurde end-to-end-organisaties zijn, want deze vereisen binnen alle schakels controleurs. Bovendien vallen lokaal verankerde groepen minder op en zijn deze beter in staat om toegang te krijgen tot lokale netwerken.

Verschillende groepen werken samen binnen de cocaïnedistributieketen, maar ze hoeven elkaar niet allemaal te kennen. 


\section{Cruciale rol van malafide logistiek dienstverleners}

Op het niveau van de groothandel wordt het organiseren van de doorvoer van cocaïne en andere drugs met behulp van vrachtvervoer vaak uitbesteed aan malafide logistiek dienstverleners (informatie uit opsporingsonderzoeken en interviews; Kruisbergen e.a., 2019). Uit de door ons bestudeerde politie-informatie komt naar voren dat zij facilitators zijn met veel macht en invloed. Leveranciers en afnemers zijn in sterke mate van hen afhankelijk. De malafide logistiek dienstverlener neemt in de doorvoerhandel een autonome positie in en kan bepalen welke drugshandelaren van zijn distributielijn gebruik mogen maken, hoe het transport plaatsvindt, welke drugs worden vervoerd en waar wordt afgeleverd. Daarmee verkeren leverancier en afnemer in een afhankelijkheidsrelatie ten opzichte van de malafide logistiek dienstverlener.

Malafide logistiek dienstverleners kunnen door verschillende netwerken worden ingezet voor het organiseren en uitvoeren van het transport. Ze hebben kennis van en toegang tot de transportwereld om de doorvoer te kunnen realiseren, wat hen een belangrijke schakel in het doorvoerproces maakt.

\section{Discussie en vervolgonderzoek}

Ons onderzoek laat zien dat de organisatie van de distributie van cocaïne en andere drugs kan worden beschouwd als een interdependent netwerk van netwerken, waarin verschillende criminele netwerken interacteren en van elkaar afhankelijk zijn (vgl. Gao e.a., 2014). Door de georganiseerde misdaad vanuit een netwerken-van-netwerken-perspectief te analyseren, kan inzicht worden verkregen in de mate van samenwerking tussen schijnbaar onafhankelijke groepen.

Binnen de (multidisciplinaire) bestudering van netwerken is er het afgelopen decennium meer aandacht besteed aan het principe van netwerken van netwerken (networks of networks/NoN - Gao e.a., 2014). De oorsprong kan worden gezien in chaos- en complexiteitstheorieën, en in het bijzonder de ideeën rondom complex adaptieve systemen. Een belangrijk uitgangspunt in het NoN-perspectief is dat individuele netwerken zeer zelden geïsoleerde, opzichzelfstaande netwerken zijn, maar onderdeel vormen van een groter geheel van netwerken (vgl. Yadav e.a., 2020). Daarbij is sprake van interactie en interdependentie tussen de verschillende netwerken (Havlin e.a., 2014). Het NoN-perspectief is in zwang geraakt als metafoor in de bestudering van de microwereld van het brein en de macrowereld van het internet. In de criminologie komen we de term onder meer tegen in de bestudering van cybercrime (McCusker, 2006) en Al Qaida (Kenney, 2003). Overeenkomstig met de netwerkvorm van organiseren (vgl. Powell, 1990) is ook hier sprake van afwezigheid van centrale sturing of supervisie van bovenaf (vgl. Jackson, 2006). Organisatorisch levert dit een flexibele en autonome manier van samenwerken op waarin netwerken hun mogelijkheden ontlenen aan de hun beschikbare vaardigheden en toegang tot bronnen.

In de bestudering van criminele NoN komen we verschillende typeringen van netwerken van netwerken tegen, waaronder interdependent en interconnected networks. Daarnaast worden termen als multilayer of multiplex networks gehanteerd. In de regel verwijzen deze naar verschillende typen relaties tussen actoren en daarmee 
naar de gelaagdheid in een netwerk (vgl. Bright e.a., 2015). Toledo en collega's (2020) stellen dat gelaagdheid daarnaast ook het gevolg kan zijn van het feit dat subjecten gelijktijdig in verschillende criminele netwerken kunnen participeren. Multilayer of multiplex networks zijn daarmee eerder netwerken in netwerken dan netwerken van netwerken.

Met uitzondering van de studie van Bahulkar en collega's (2018) naar geldsmokkel en witwassen, hebben wij geen studies gevonden van criminele NoN op meso- of macroniveau, maar alleen studies op microniveau. Oftewel, het principe van NoN lijkt voor zover wij weten vooralsnog met name toegespitst op het nader duiden van criminele egonetwerken en niet op de complete netwerken of whole networks. Onze bevindingen laten zien dat kleinschalige doorvoer van cocaïne en andere drugs weliswaar gerealiseerd kan worden binnen één crimineel samenwerkingsverband (microniveau), maar zeker voor wat betreft groot- en tussenhandel vooral het werk is van verschillende netwerken die deelaspecten van de distributie voor hun rekening nemen. Wij stellen dat op het mesoniveau transnationale NoN de drugshandel realiseren. Oftewel, het NoN-perspectief behelst een verschuiving van een micro- naar een meso-invalshoek op de handel (vgl. Spapens, 2012).

In die zin onderscheidt het door ons gehanteerde perspectief zich ook van studies van co-offending relaties. Tenti en Morselli (2014) laten bijvoorbeeld in hun onderzoek naar drugsdistributie zien dat er verschillen zijn in hoe er binnen netwerken wordt samengewerkt. Zij stellen daarbij dat grote netwerken zoals de 'Ndrangheta en Albanese criminele groepen een hoge mate van co-offending kennen en dat deze groepen in de volledige drugsdistributieketen betrokken zijn. Opmerkelijk is dat wij op basis van het meso-NoN-perspectief precies het tegenovergestelde observeren. Namelijk dat grootschalige end-to-end-handel eerder het werk is van interdependente, losse netwerken, waarbij het onwaarschijnlijk is dat één groep (zoals de maffia) het overzicht en de coördinatie heeft over de gehele distributieketen.

Behalve dat transcriminaliteit in het algemeen en de drugshandel in het bijzonder vrijwel nooit vanuit NoN-perspectief zijn bestudeerd, zijn ook onderzoeken naar het transnationale aspect van doorvoerhandel dun gezaaid. Transnationale stromen van cocaïne en heroïne zijn wel bestudeerd (Chandraa \& Jobab, 2015). Echter, in deze studie worden drugsstromen (flows) afgeleid van data over drugsprijzen per land zoals gerapporteerd door onder meer het UNODC. In ons onderzoek hebben we naast secundaire bronnen ook primair transnationaal empirisch materiaal kunnen bestuderen. Het resultaat hiervan is dat het transnationale NoN-perspectief in onze studie bepaalde mechanismen heeft blootgelegd die anders niet in het vizier waren gekomen. De pingponghandel is hier een voorbeeld van. Onze bevindingen tonen aan dat de drugshandel niet een lineaire flow van drugs - van productie, via tussenpersonen, naar consumenten - is waar in elke stap van de waardeketen waarde wordt toegevoegd, zoals Hastings (2015) stelt. In plaats hiervan laten onze bevindingen zien dat het een multidirectionele waardeketen betreft (vgl. Henderson e.a., 2002). Overeenkomstig recente inzichten in de (mondiale) supply chain-literatuur kan de doorvoerhandel hier met recht getypeerd worden als transnationale waardenetwerk (vgl. Galanis \& Kumar, 2021).

Alleen een transnationaal NoN-perspectief legt de herinvoer en heruitvoer bloot, essentieel voor een beter begrip van de doorvoerhandel. Op basis van de bevindin- 
gen van ons exploratieve onderzoek constateren wij dat veel van de actieve netwerken niet beschikken over directe contacten met groothandelaren en zijn aangewezen op de contacten van de contacten. Pingponghandel komt dus tot stand omdat de netwerken in de groothandel vooral met netwerken in de tussenhandel werken die in Nederland gevestigd zijn. De actoren uit deze netwerken beschikken over contacten met de internationale netwerken, waaronder contacten met netwerken uit de doorvoerlanden. Al komt het ook voor dat er nog een schakel zit tussen de netwerken. De waardetoevoeging in Nederland is in dat geval te kenschetsen als de toevoeging van sociaal en/of menselijk kapitaal (vgl. Ruggiero \& Khan, 2006).

De transnationale invalshoek van onze studie heeft tevens de transformatie van mono- naar polyhandel blootgelegd. Zoals we al geobserveerd hebben, is de polydrugshandel niet een uniek Nederlands fenomeen. De transformatie van mononaar polydrugshandel kan onder andere gezien worden als een manier van risicospreiding voor de betrokken criminele groepen, om zodoende de weerbaarheid en het aanpassingsvermogen van het criminele netwerk te verhogen (vgl. Diviák e.a., 2020). Tegelijkertijd vereist de polydrugshandel meer verbindingen tussen handelaren dan in de monodrugshandel het geval is (Hughes e.a., 2016), en levert dat weer meer risico's op. Wat specifiek de betekenis is van de transformatie van mono naar poly is tot op heden nog niet bekend. Wederom moeten we ons hier afvragen wat hiervan specifiek de waardetoevoeging is, en of dit een uniek kenmerk is voor de Nederlandse doorvoerhandel of voor drugsdistributiehubs in het algemeen.

Het NoN-perspectief onderstreept ten slotte het belang van brokers. Brokers leggen de verbinding tussen netwerken die anders van elkaar gescheiden zouden zijn (Burt, 1992). De broker dankt zijn positie aan het feit dat hij tussen partijen zit en dus netwerken kan verbinden (Kleemans e.a., 2002). De broker kan bijvoorbeeld barrières overbruggen bij het contact leggen met andere netwerken, zoals tussen landen, etnische groepen en tussen onder- en bovenwereld (Kleemans e.a., 2002). In ons onderzoek is naar voren gekomen dat de malafide logistiek dienstverlener in Nederland een brokerfunctie heeft doordat deze de verschillende netwerken met elkaar verbindt. De rol van malafide logistiek dienstverlener overbrugt dus als het ware een structural hole tussen twee netwerken (Burt, 1992). Daarmee zijn malafide logistiek dienstverleners binnen de doorvoer van cocaïne via Nederland te beschouwen als sleutelfiguren. Het kan daarbij gaan om sets van individuele sleutelfiguren/key players (Borgatti, 2006), die niet per se een groep als zodanig vormen, of het zou wellicht kunnen gaan om sleutelgroepen/key groups (Temurshoev, 2008), die zorg dragen voor de verbinding tussen verschillende netwerken. Uit vervolgonderzoek naar de malafide logistiek dienstverlener binnen de doorvoer van drugs (Vermeulen, 2019) is gebleken dat het een sleutelfiguur betreft die dankzij zijn kennis van en toegang tot de transportwereld in staat is drugstransporten te realiseren (menselijk kapitaal). Ook is hij een sleutelfiguur op basis van de positie die hij inneemt tussen en binnen verschillende (criminele) netwerken (sociaal kapitaal). Verschillende drugsnetwerken kunnen voor het transport gebruikmaken van zijn diensten. Deze netwerken hoeven elkaar niet te kennen, maar de malafide logistiek dienstverlener kent hen wel allemaal. Hetzelfde geldt voor de afnemers in het buitenland. Malafide logistiek medewerkers zijn schaars en moeilijk vervangbaar. Hun specifieke kennis en ervaring maakt dat hun werkzaamheden niet eenvoudig door 
anderen kunnen worden uitgevoerd (vgl. Fathurrohman \& Bichler, 2020). Onderling zijn ze wel verbonden, wat maakt dat zij - hoewel ze schaars zijn - elkaars werk ook kunnen overnemen en dat ze elkaar kunnen vervangen, mocht een van hen geen logistieke activiteiten (meer) kunnen verrichten.

\section{Afhankelijkheid van drugsdoorvoernetwerken in transnationaal perspectief}

Ter validatie en verdieping van de bevindingen van het exploratieve onderzoek zou voor vervolgonderzoek een technische of kwantitatieve transnationale SNA uitgevoerd kunnen worden. Er zou hier gedacht kunnen worden aan het toepassen van SNA op cryptocommunicatiedata. De heimelijke communicatie van criminelen in dergelijke datasets overstijgt het microniveau en kan daarmee inzichten genereren op mesoniveau (zie voor een eerste aanzet: Vermeulen e.a. in dit themanummer). Voordeel van SNA is dat er niet uitgegaan wordt van op voorhand gedefinieerde groepen (social boundaries), op basis van bijvoorbeeld etniciteit of activiteit. SNA maakt het zo mogelijk om te zien hoe op basis van daadwerkelijke interactie tussen actoren groepen geclusterd kunnen worden (vgl. Bouchard, 2020). Dit voorkomt niet alleen stereotypering, het benadrukt ook het belang van voorheen onderbelichte rollen en groepen. Zo stelt Kleemans (2014) dat SNA de aandacht richt op de meer perifere groepen. Hierbij valt te denken aan de perifere maar cruciale rol van de malafide logistiek dienstverleners. Een transnationale SNA op mesoniveau (dat wil zeggen van zogenaamde whole networks) zou daarom een passende vervolgstap zijn in het onderzoek naar interdependentie van drugsdoorvoernetwerken en de hubfunctie van Nederland.

Tot op de dag van vandaag zijn SNA-studies van transnationale georganiseerde criminele netwerken op meso- of macroniveau dun gezaaid (Bouchard, 2020). Zoals wij constateren, is onderzoek naar netwerken van georganiseerde criminaliteit tot nu toe vooral gericht op de interdependentie van criminele actoren binnen een netwerk (het microniveau). Een beter begrip van de werking van de drugsdistributie in het algemeen en de hubfunctie van Nederland in het bijzonder vereist de bestudering van drugsdoorvoernetwerken vanuit de optiek van netwerken van netwerken, het mesoniveau. We vragen dus niet, zoals gebruikelijk is in de SNA, wie afhankelijk is van wie, oftewel naar de onderlinge afhankelijkheid van actoren (vgl. Kleemans, 2014), maar naar de onderlinge afhankelijkheid en verwevenheid van netwerken. Hiermee verschuift de gebruikelijke focus op sleutelfiguren naar een analyse van sets van sleutelfiguren of sleutelgroepen.

Duijn en Sloot (2015) pleiten voor de gecombineerde toepassing van SNA en crime scripting omdat het de operationele structuren alsook de interdependenties tussen de actoren binnen criminele netwerken inzichtelijk kan maken. Hierop aansluitend pleiten wij ervoor om te kijken naar de manieren waarop de interdependentie van netwerken (NoN) de verschillende activiteiten binnen de drugsdistributie via $\mathrm{Ne}$ derland 'script'. Welke netwerken of sets van sleutelfiguren/sleutelgroepen bevinden zich in welke positie van drugsdistributieketens en zijn in welke mate afhankelijk van elkaar of bepalend voor het distributieproces (vgl. Borgatti \& Li, 2009)? Een dergelijke combinatie van SNA en supply chain management wordt wel toegepast in de organisatieliteratuur (Wichmann \& Kaufmann, 2016), maar is tot nu toe nog niet gebruikt voor de bestudering van criminele markten. Vervolgonderzoek 
zou zich dan ook moeten richten op malafide logistiek dienstverleners of op andere facilitators of brokers die een belangrijke rol spelen bij de verbinding tussen de verschillende niveaus van de markt alsook bij de transformatie van mono- naar polydrugshandel.

Voor een completer beeld van het netwerk van netwerken in de transnationale drugsdistributie zou vervolgonderzoek zich ook moeten richten op het in kaart brengen van het (Europese) grensoverschrijdende netwerk van netwerken, waarbij niet alleen de stromen van mensen en handelswaar, maar uitdrukkelijk ook die van transportmiddelen en financiën gemoeid met de drugshandel meegenomen moeten worden. Behalve het soort stromen vereist de bestudering van drugsdistributie ook het in kaart brengen van de richting van deze stromen. Dit zal naar verwachting de complexiteit van de pingponghandel verder blootleggen.

Ten slotte is voor de verdere bestudering van de transnationale drugsdistributie een dynamische invalshoek gewenst. Zoals Bichler en Malm (2013) stellen, brengt de dynamische bestudering van handelsstromen de verborgen structuren van criminele netwerken aan het licht. De reden hiervoor is dat de herinvoer en/of heruitvoer van handelswaar pas zichtbaar worden bij metingen in de tijd, omdat er immers niet gelijktijdig sprake is van import en export van dezelfde handelswaar. $\mathrm{Al}$ met al zal het SNA-vervolgonderzoek naar drugsdistributie erop gericht moeten zijn om een nieuw theoretisch raamwerk te ontwikkelen, dat recht doet aan de complexiteit van de transnationale netwerken van netwerken in de doorvoerhandel, en om beter te begrijpen hoe de verschillende niveaus van netwerken in elkaar grijpen.

\section{Ter afsluiting}

In dit artikel benadrukken wij het belang van een transnationaal netwerken-van-netwerken-perspectief (TNoN) voor een beter begrip van de doorvoerhandel en de werking van Nederland als transithub in de drugsdistributie. Een dergelijke invalshoek in het onderzoek naar de doorvoerhandel legt bepaalde mechanismen bloot, zoals de gelijktijdige herinvoer en heruitvoer van handelswaar alsook de verwevenheid van de verschillende niveaus van de handel over landsgrenzen heen.

Ook ten behoeve van opsporen en handhaven is het hanteren van een transnationaal NoN-perspectief op de doorvoerhandel gewenst. Zo ligt vandaag de dag bij de controle van goederen het zwaartepunt op de binnenkomende stromen, maar lijkt het verstandig om daarnaast prioriteit te geven aan de controle en monitoring van uitgaande stromen. Hierop aansluitend is het aan te raden gezamenlijke, internationale controles op personen en goederen uit te voeren. Het is eveneens wenselijk om internationale intelligence over drugsstromen op Europees niveau verder uit te bouwen. Internationale politiesamenwerking vindt vooralsnog vooral plaats op het microniveau van opsporingsonderzoeken en nog nauwelijks op meso- en macroniveau. Een transnationaal NoN-perspectief op de doorvoerhandel via Nederland vergt niet alleen de aanlevering van data vanuit de verschillende bestemmingslanden van via Nederland verhandelde drugs, maar ook de uitwisseling van kennis over de handel door de betreffende domeinexperts. Een meer internationale blik 
en aanpak zijn noodzakelijk om de transnationale drugsnetwerken van netwerken beter te kunnen doorgronden en bestrijden.

\section{Literatuur}

Bahulkar, A., Orkun Baycik, N., Sharkey, T., Shen, Y., Szymanski, B. \& Wallace, W. (2018). Integrative analytics for detecting and disrupting transnational interdependent criminal smuggling, money, and money-laundering networks. International Symposium on Technologies for Homeland Security. Woburn, MA.

Baldwin, R. (2017). Factory-free Europe? A two unbundlings perspective on Europe's 20th century manufacturing miracle and 21st century malaise. In: L. Fontagné \& A. Harrison (eds.). The Factory-Free Economy: Outsourcing, Servitization and the Future of Industry. Oxford: Oxford University Press, 24-66.

Bichler, G. \& Malm, A. (2013). Small arms, big guns. A dynamic model of illicit market opportunity. Global Crime, 14(2-3), 261-286.

Blickman, T., Korf, D.J., Siegel, D. \& Zaitch, D. (2003). Synthetic drug trafficking in Amsterdam. In: Gruppo Abele/TNI-IECAH \& UNICRI, Synthetic Drugs Trafficking in Three European Cities: Major Trends and the Involvement of Organised Crime. S.n., 17-94.

Boerman, F., Grapendaal, M., Nieuwenhuis, F. \& Stoffers, E. (2017). Nationaal dreigingsbeeld 2017. Georganiseerde criminaliteit. Driebergen: Landelijke Eenheid, Dienst Landelijke Informatieorganisatie.

Boivin, R. (2014). Drug trafficking networks in the world economy. In: C. Morselli (ed.). Crime and Networks. New York: Routledge, 182-191.

Borgatti, S.P. (2006). Identifying sets of key players in a social network. Computational and Mathematical Organization Theory, 12(1), 21-34.

Borgatti, S.P. \& Li, X. (2009). On social network analysis in a supply chain context. Journal of Supply Chain Management, 45(2), 5-22.

Bouchard, M. (2020). Collaboration and boundaries in organized crime. A network perspective. Crime and Justice, 49(1), 425-469.

Bright, D.A., Greenhill, C., Ritter, A. \& Morselli, C. (2015). Networks within networks: using multiple link types to examine network structure and identify key actors in a drug trafficking operation. Global Crime, 16(3), 219-237.

Bunt, H.G. van de \& Kleemans, E.R. (2007). Georganiseerde criminaliteit in Nederland. Derde rapportage op basis van de Monitor Georganiseerde Criminaliteit. Den Haag: Boom Juridische uitgevers.

Burt, R.S. (1992). Structural Holes. The Social Structure of Competition. Cambridge: Harvard University Press.

Chandraa, S. \& Jobab, J. (2015). Transnational cocaine and heroin flow networks in western Europe: a comparison. International Journal of Drug Policy, 26, 772-780.

De Middeleer, F., Van Nimwegen, S., Ceulen, R., Gerbrands, S. \& Roevens, E. (2018). Illegale drugsmarkten in België en Nederland: communicerende vaten? Brussel: Belgian Science Policy Office (BELSPO).

DEA (Drug Enforcement Agency). (2019). National Drug Threat Assessment.

Diviák, T., Dijkstra, J.K. \& Snijders, T.A.B. (2020). Poisonous connections. A case study on a Czech counterfeit alcohol distribution network. Global Crime, 21(1), 51-73.

Duijn, P.A.C. \& Sloot, P.M.A. (2015). From data to disruption. Digital Investigation, 15, 3945.

Europol (2015). Exploring Tomorrow's Organised Crime. S.l.: European Police Office.

Europol (2017). SOCTA 2017. European Union. Serious and Organised Crime Threat Assessment. Crime in the Age of Technology. The Hague: European Police Office. 
Fathurrohman \& Bichler, G. (2020). Explaining the positional importance of actors involved in trafficking methamphetamine into Indonesia. Global Crime, 1-30. doi.org/10.1080/1 7440572.2020 .1819249$.

Galanis, G. \& Kumar, A. (2021). A dynamic model of global value network governance. Environment and Planning A, 53(1), 53-72.

Gao, J., Li, D. \& Havlin, S. (2014). From a single network to a network of networks. National Science Review, 1(3), 346-356.

Gruter, P. \& Mheen, D. van de (2005). Cocaïnehandel in Nederland. Impressies van deelnemers aan drugsdistributienetwerken. Rotterdam: IVO.

Hastings, J.V. (2015). The economic geography of North Korean drug trafficking networks. Review of International Political Economy, 22(1), 162-193.

Havlin, S., Kenett, D.Y., Bashan, A., Gao, J. \& Stanley, H.E. (2014). Vulnerability of network of networks. The European Physical Journal Special Topics, 223, 2087-2106.

Heijden, A.W.M. van der (2003). De Nederlandse drugsmarkt. Een poging tot kwantificering van import, export, productie en consumptie van verdovende middelen. Zoetermeer: KLPD-DNRI.

Henderson, J., Dicken, P., Hess, M., Coe, N. \& Yeung, H.W. (2002). Global production networks and the analysis of economic development. Review of International Political Economy, 9, 436-464.

Hughes, C.E., Bright, D.A. \& Chalmers, J. (2017). Social network analysis of Australian poly-drug trafficking networks. How do drug traffickers manage multiple illicit drugs? Social Networks, 51, 135-147.

Hughes, C., Chalmers, J., Bright, D. \& McFadden, M. (2016). Trafficking in Multiple Commodities. Exposing Australia's Poly-Drug and Poly-Crime Networks. Monograph No. 62. Canberra: National Drug Law Enforcement Research Fund.

Innes, M., Fielding, N. \& Cope, N. (2005). The appliance of science? The theory and practice of crime intelligence analysis. The British Journal of Criminology, 45(1), 39-57.

Jackson, B.A. (2006). Groups, networks, or movements: a command-and-control-driven approach to classifying terrorist organizations and its application to Al Qaeda. Studies in Conflict \& Terrorism, 29, 241-262.

Kenney, M. (2003). From Pablo to Osama: counter-terrorism lessons from the war on drugs. Survival, 45(3), 187-206.

Kleemans, E.R. (2014). Theoretical perspective on organized crime. In: L. Paoli (ed.). The Oxford Handbook of Organized Crime. Oxford: Oxford University Press, 32-52.

Kleemans, E.R., Brienen, M.E.I. \& Bunt, H.G. van de (2002). Georganiseerde criminaliteit in Nederland. Tweede rapportage op basis van de WODC-monitor. Den Haag: WODC.

Kruisbergen, E.W., Bunt, H.G. van de \& Kleemans, E.R. (2012). Georganiseerde criminaliteit in Nederland. Vierde rapportage op basis van de Monitor Georganiseerde Criminaliteit. Den Haag: Boom Lemma.

Kruisbergen, E.W., Roks, R.A. \& Kleemans, E.R. (2019). Georganiseerde criminaliteit in Nederland: daders, verwevenheid en opsporing. Rapportage in het kader van de vijfde ronde van de Monitor Georganiseerde Criminaliteit. Den Haag: WODC.

Laar, M.W. van, Cruts, A.A.N. \& Miltenburg, C.J.A. van (red.) (2020). Nationale Drug Monitor. Jaarbericht 2019. Utrecht/Den Haag: Trimbos-instituut/WODC.

Luxton, I. \& Sbicca, J. (2020). Mapping movements: a call for qualitative social network analysis. Qualitative Research, 1-20. doi:10.1177/1468794120927678.

McCusker, R. (2006). Transnational organised cyber crime: distinguishing threat from reality. Crime, Law and Social Change, 46, 257-273.

Meloen, J.D. (2016). Criminele relaties tussen Nederland en andere landen 2015. Een update en analyse van de intensiteit en trend. Zoetermeer: DLIO, Landelijke Eenheid.

Ministerie van Veiligheid en Justitie, Directoraat-Generaal Rechtspleging en Rechtshandhaving (2017). Cerca Trova. Een analyse van de Italiaanse maffia in Nederland. S.l., s.n. 
Nieuwenhuis, F., Dedert, P. \& Mulder, T. (2016). Cocaïne. Politie interne rapportage voor het Nationaal dreigingsbeeld 2017. N.g.

Powell, W.W. (1990). Neither market nor hierarchy. Network forms of organization. Research in Organizational Behavior, 12, 295-336.

Ruggiero, V. \& Khan, K. (2006). British South Asian communities and drug supply networks in the UK: a qualitative study. International Journal of Drug Policy, 17, 473-483.

Spapens, A.C.M. (2012). Netwerken op niveau: criminele micro-, meso- en macronetwerken. Inaugurele rede Tilburg University. Tilburg: Prisma Print.

Staring, R., Bisschop, L., Roks, R., Brein E. \& Bunt, H. van de (2019). Drugscriminaliteit in de Rotterdamse haven: aard en aanpak van het fenomeen. Erasmus Universiteit Rotterdam, Erasmus School of Law.

Temurshoev, U. (2008). Who's who in networks. Wanted: the key group. NET Institute working paper 08-08, 1-25.

Tenti, V. \& Morselli, C. (2014). Group co-offending networks in Italy's illegal drug trade. Crime Law Social Change, 62, 21-44.

Toledo, A.S.O., Carpi, L.C. \& Atman, A.P.F. (2020). Diversity analysis exposes unexpected key roles in multiplex crime networks. In: H. Barbosa, J. Gomez-Gardenes, B. Gonçalves, G. Mangioni, R. Menezes \& M. Oliveira (eds.). Complex Networks XI. Proceedings of the 11th Conference on Complex Networks CompleNet 2020. Cham: Springer.

Tops, P., Valkenhoef, J. van, Torre, E. van der \& Spijk, L. van (2018). Waar een klein land groot in kan zijn. Nederland en synthetische drugs in de afgelopen 50 jaar. Den Haag: Boom criminologie.

UNODC (United Nations Office on Drugs and Crime). (2020). World Drug Report 2020. Vol. 3: Drug supply. Vienna.

Vermeulen, I. (2019). De malafide logistiek dienstverlener. Sleutelfiguur in de doorvoer van verdovende middelen van Nederland naar het buitenland. Driebergen: Dienst Landelijke Informatieorganisatie. Gevonden op: www.politieacademie.nl/kennisenonderzoek/ kennis/mediatheek/PDF/96334.PDF.

Vermeulen, I., Leest, W. van der \& Dirksen, V. (2018). De doorvoer van cocaïne via Nederland. Distributielijnen en doorvoermethoden. Driebergen: Dienst Landelijke Informatieorganisatie. Gevonden op: ww.politieacademie.nl/kennisenonderzoek/kennis/mediatheek/ PDF/94995.PDF.

Wichmann, B.K. \& Kaufmann, L. (2016). Social network analysis in supply chain management research. International Journal of Physical Distribution \& Logistics Management, 46(8), 740-762.

Wijk, A. van \& Bremmers, B. (2011). Snelle jongens. Een onderzoek naar drugsrunners en daaraan gerelateerde problematiek in Limburg-Zuid. S.l.: Bureau Beke.

Yadav, N., Chatterjee, S. \& Ganguly, A.R. (2020). Resilience of urban transport network-of-networks under intense flood hazards exacerbated by targeted attacks. Scientific Reports, 10(1), 10350.

Yousefi Nooraie, R., Joanna E.M., Sale, J.E.M., Marin, A. \& Ross, L.E. (2018). Social network analysis: an example of fusion between quantitative and qualitative methods. Journal of Mixed Methods Research,14(1), 110-124.

Zaitch, D. (2002). Trafficking Cocaine. Colombian Drug Entrepreneurs in the Netherlands. The Hague: Kluwer Law International. 